\title{
Effects of Pollution on the Amino Acid Content of Mytilus edulis
}

\author{
RITA D. SCHAFER ${ }^{1}$
}

\begin{abstract}
In an attempt to determine the influence of polluted water on the amino acid content of Mytilus edulis, muscle tissue of specimens from a clean area was compared with that of specimens from polluted areas and with that of specimens transferred from clean to polluted water. Analyses were made by means of two-dimensional paper chromatography. The amino acids present under one type of environmental condition but not under another were cystine, cysteine, methionine, taurine/asparagine, and proline.
\end{abstract}

IT has long been known that marine waters containing pollutants affect in various ways the fauna inhabiting such waters. A number of studies have shown that pollution factors aid the settlement and growth of some species while inhibiting others. Wilhelmi (1916) points out that some species are so favored by such an area that they occur in numbers sufficient to permit them to be considered as pollutant indicators. Reish (1955, 1956, 1957a, 1957b) calls attention to the presence of Capitella capitata in all areas of pollution in southern California; and in a later study (1960), in which he classifies areas as to degree of pollution, he points out that each type of area is characterized by the presence of dominant species of polychaetes. Hartman (1950) states that near a disposal outfall in Santa Monica Bay, California, only two major groups of animals are present, the annelids and the crustaceans. Filice (1959) in discussing the distribution of bottom fauna in polluted estuarine waters, states that the occurrence of some species as well as their concentrations will vary with the nature and degree of pollution. Blevgad (1932), investigating effects of pollution on bottom fauna, found "dead" areas at the point of sewage outfalls. He points out, however, that at a distance slightly over $100 \mathrm{~m}$ away, conditions are the same as at a greater distance.

\footnotetext{
${ }^{1}$ Allan Hancock Foundation, University of Southern California, and Immaculate Heart College, Los Angeles, California. Manuscript received December 22, 1961.
}

McNulty (1957), in a study of the effects of pollution in Biscayne Bay adjacent to the Miami shoreline, indicates that pollution in some instances has had a beneficial effect on productivity of macroorganisms. Hartman (1960), summarizing the results of extensive selected sampling of 11 southern California coastal areas, states that productivity and variation of organisms differ according to types of sediments, depth of bottom, availability of food, and effects of waste discharges. She also noted that biomass values are lowest in shallow depths of Santa Monica Bay, an area into which the largest of the Los Angeles disposal plants empties. The biomass values of this region were comparable to those from oily samples taken in a more northern area. In addition to these variations in ability to survive and, in some cases, to thrive in waters containing pollutants, it has been noted that the biochemical composition of some forms living in such an environment differs from that of the same species from clean waters (Schafer, 1961). Forms previously used for investigation were the abalone, Haliotis cracherodii, and the crab, Pachygrapsus crassipes. In these the free amino acids present in specimens from polluted areas were compared with those from nonpolluted areas.

It is the purpose of the present study not only to evaluate the differences in amino acids in another organism from clean and polluted areas, but to investigate as well the effect upon 
the free amino acids of transfer from a clean area to a polluted one.

\section{ACKNOWLEDGMENTS}

The author is indebted to the administration of the Allan Hancock Foundation for the use of laboratory facilities. This study was supported by a research grant from the United States Public Health Service of the National Institute of Health, no. RG-4911.

\section{MATERIALS AND METHODS}

In the present study the wharf mussel, Mytilus edulis, was selected for investigation. Its wide occurrence made it easily available from a variety of areas of varying environmental conditions. Because of its sessile nature and presence on floats, it was possible to use specimens which had been constantly subjected to the conditions prevailing in the area from which it was taken. No attempt was made to differentiate sexes or size of specimens, as preliminary tests showed no amino acid differences in these respects in this species.

Comparisons of free amino acids were made on muscle tissue of animals from (1) different polluted areas, (2) an area considered free of pollution, and (3) from animals transferred from a nonpolluted area to areas of pollution. In addition, muscle tissue hydrolysates of specimens from the clean area were compared with hydrolysates of individuals from the polluted areas.

The sites chosen for study were a small yacht marina in the Los Angeles Harbor, designated here and in previous studies of water pollution as L.A. 7; a dock in slip I of the main channel, identified as L.A. 39; and a third area of pollution in Cerritos Channel of Long Beach Harbor, L.B. 23 (Fig. 1).

Specimens from a nonpolluted area were taken at Tomales Bay, north of San Francisco.

To establish the normal free amino acid pattern of $M$. edulis, specimens were taken from the Tomales Bay area, returned to the laboratory alive where muscle tissue was excised, quick frozen with dry ice, lyophilized, and extracted with $70 \%$ cold ethanol. Hydrolysates were prepared by hydrolysis of excised muscle with $6 \mathrm{~N}$

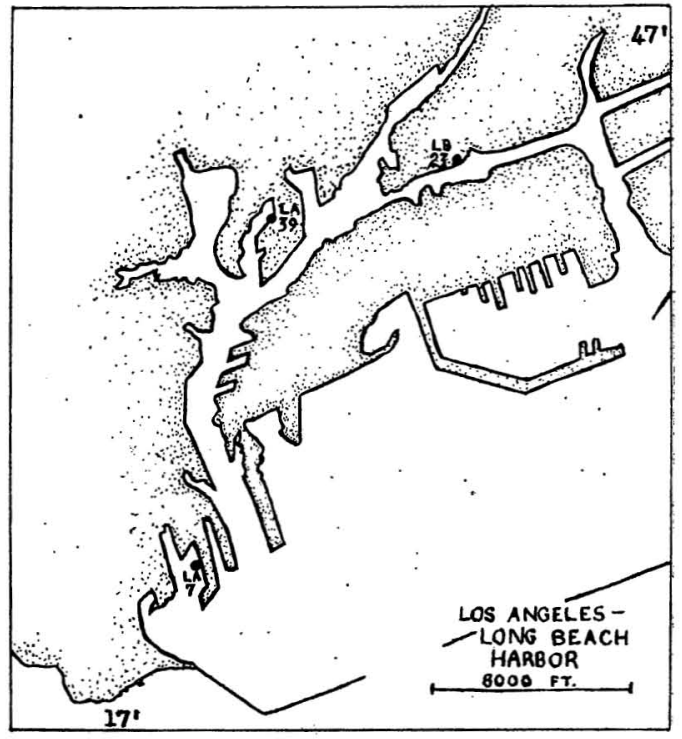

FIG. 1. Areas of pollution from which collections were made.

$\mathrm{HCl}$ and desalted with $70 \%$ cold ethanol. Best results were obtained by serial studies using different amounts of a given extract. By limiting the amount of extract on one paper to a minimal quantity necessary for resolution, those amino acids ordinarily present in quantities so large that adjacent spots tended. to merge upon development remained distinct and compact. By placing large amounts of extract on a second paper those amino acids present in trace quantities could be detected upon development, while those present in large amounts, already determined in the first run, merged and became indistinguishable.

To determine whether or not differences in free amino acid metabolism existed in M. edulis under conditions of pollution, specimens were collected from polluted areas mentioned above, and treated in an identical manner.

Assuming that a difference might exist between these two groups with respect to free amino acids, as it had in other forms, an attempt was made to learn whether a change would occur following transfer from the nonpolluted to the polluted areas. Specimens from Tomales Bay were tagged for identification, placed in plastic containers through which a free exchange of water was possible, and placed in the polluted 
TABLE 1

Free AND Protein-Bound Amino ACIDS Present In SPECIMENS of Mytilus edulis From Three POlluted AREAS, ONE NONPOlLUTED AREA, AND TRANSFERrED SPECIMENS

\begin{tabular}{|c|c|c|c|c|c|c|c|c|c|c|c|c|c|c|c|c|c|c|}
\hline & 㟧 & 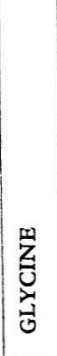 & 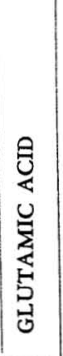 & $\begin{array}{l}\underset{\mathbf{Z}}{\mathbf{z}} \\
\text { 息 }\end{array}$ & 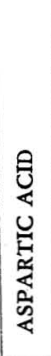 & $\begin{array}{l}\text { 㗄 } \\
\text { 总 } \\
\text { 总 } \\
\text { 总 }\end{array}$ & 罯 & 觉 & $\frac{\mathrm{m}}{\mathrm{z}}$ & 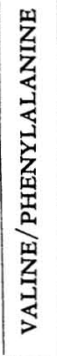 & 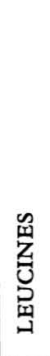 & 㬅 & 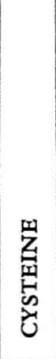 & $\begin{array}{l}\text { 圆 } \\
\text { : } \\
\text { 品 }\end{array}$ & 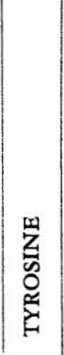 & $\begin{array}{l}\text { 罢 } \\
\text { 莧 } \\
\text { 㩊 }\end{array}$ & 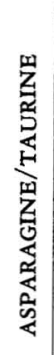 & 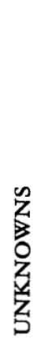 \\
\hline \multicolumn{19}{|c|}{$\begin{array}{l}\text { Free Amino Acids } \\
\text { Polluted areas }\end{array}$} \\
\hline L. A. 7 & $x$ & $x$ & $x$ & $x$ & $x$ & $x$ & $x$ & $x$ & $x$ & $x$ & $x$ & $x$ & & $x$ & & $x$ & & 2 \\
\hline L. A. 39 & $x$ & $x$ & $x$ & $x$ & $x$ & $x$ & $x$ & $x$ & $x$ & $x$ & $x$ & $x$ & & $x$ & & $x$ & & 3 \\
\hline L. B. 23 & $x$ & $x$ & $x$ & $x$ & $\bar{x}$ & $x$ & $x$ & $x$ & $x$ & $x$ & $x$ & $x^{-}$ & & $x$ & & $x$ & & 1 \\
\hline \multicolumn{19}{|c|}{$\begin{array}{l}\text { Free Amino Acids } \\
\text { Nonpolluted area }\end{array}$} \\
\hline Tomales Bay & $x$ & $x$ & $x$ & $x$ & $x$ & $x$ & $x$ & $x$ & $x$ & $x$ & $x$ & & & $x$ & & $x$ & & 3 \\
\hline \multicolumn{19}{|c|}{$\begin{array}{l}\text { Free Amino Acids } \\
\text { Transferred }\end{array}$} \\
\hline To L. A. 39 & $x$ & $x$ & $x$ & $x$ & $x$ & $x$ & $x$ & $x$ & $x$ & $x$ & $x$ & & & & & & $x$ & \\
\hline To L. B. 23 & $x$ & $x$ & $x$ & $x$ & $x$ & $x$ & $x$ & $x$ & $x$ & $x$ & $x$ & & & & & & $x$ & \\
\hline & & & & & & & & & & & & & & & & & & \\
\hline \multicolumn{19}{|l|}{ Hydrolysates } \\
\hline L. A. 7 & $x$ & $x$ & $x$ & $x$ & $x$ & $x$ & $x$ & $x$ & $x$ & $x$ & $x$ & $x$ & $x$ & $x$ & $x$ & $\bar{x}$ & & 3 \\
\hline L. A. 39 & $x$ & $x$ & $x$ & $x$ & $x$ & $x$ & $x$ & $x$ & $x$ & $x$ & $x$ & $\bar{x}$ & $x$ & $x$ & $x$ & $x$ & & 2 \\
\hline L. B. 23 & $x$ & $x$ & $x$ & $x$ & $x$ & $x$ & $x$ & $x$ & $x$ & $x$ & $x$ & $x$ & $x$ & $x$ & $x$ & $x$ & & \\
\hline Tomales Bay & $x$ & $x$ & $x$ & $x$ & $x$ & $x$ & $x$ & $x$ & $x$ & $x$ & $x$ & $\times$ & & $x$ & & $x$ & & \\
\hline
\end{tabular}

areas. After 10 days these specimens were removed and analyzed for free amino acid content in the manner described above. The terminal survival point for transferred animals occurred between 10 and 15 days.

\section{RESULTS}

Chromatograms made of the free amino acid extracts of specimens from clean water showed the presence of alanine, glycine, glutamic acid, serine, aspartic acid, threonine, lysine, histidine, arginine, valine, leucines, methionine, proline, plus three unidentified spots.

Native specimens from L.A. 39, L.A. 7, and L.B. 23, all polluted areas, contained alanine, glycine, glutamic acid, serine, aspartic acid, thre- onine, lysine, histidine, arginine, valine, leucines, proline, cystine, and methionine, plus two unidentified spots in the case of L.A. 7 and three each on the chromatograms of L.A. 39 and L.B. 23. (See Table 1.)

The specimens taken from Tomales Bay and transferred to the polluted waters of L.A. 39 and L.B. 23 contained well-defined spots of alanine, glycine, glutamic acid, serine, aspartic acid, threonine, lysine, histidine, arginine, valine, leucines, and taurine/asparagine.

The hydrolysate of specimens from Tomales Bay contained alanine, glycine, glutamic acid, serine, aspartic acid, threonine, lysine, histidine, arginine, valine, methionine, leucines, cystine, and proline. 
Hydrolysates of specimens from L.A. 7, L.A. 39, and L.B. 23 contained those amino acids reported above for the Tomales Bay specimens, plus tyrosine and cysteine. The spot indicative of valine assumed a shape which suggests that phenylalanine may also be present. In the case of L.A. 7 three unidentified amino acids were present also; in the case of L.B. 23, two.

\section{DISCUSSION}

An analysis of the free amino acids present in specimens from the three types of situation indicated above shows that 11 of these occurred in all forms. Those specimens taken from polluted water contained proline, cystine, and methionine as well. Those from nonpolluted water contained the proline and methionine but lacked the cystine. The chromatograms of those specimens which had been transferred from clean to polluted waters lacked all three of these free amino acids, proline, methionine, and cystine. Taurine/asparagine, not found in any of the others, either from clean or polluted water, is clearly discernible on the chromatograms of the transferred specimens.

The nature of the pollutants involved in contributing to these differences has not been specifically determined. The data compiled by the Los Angeles Bureau of Sanitation (1957), covering the periods. August 1956 to February 1957, show oxygen depletion and increased coliform bacterial counts for the areas covered in this study. Reish (1960) summarizing characteristics of the areas classifies L.A. 7 and L.B. 23 as "healthy bottom" areas and lists a dissolved oxygen at $6.0 \mathrm{ppm}$ for the median at the surface. He classifies L.A. 39 as "very polluted bottom" with a dissolved oxygen of $1.6 \mathrm{ppm}$. In describing the nature of the substrate he indicated the presence of black sulfide mud in each instance. A visually obvious pollutant at all three stations is an oily substance. The concentration of this at L.A. 39 is such that all submerged structures appear to have a tarlike coating. Water circulation at this point seems to be limited to that produced by tidal fluctuation.

Whatever the composition of the pollutants, they seem to contain factors which have influenced the metabolism of the sulfur-containing amino acids, cystine and methionine. It is known that methionine can be converted to cystine, and that cystine and methionine, via cysteine, in mammals can act as a precursor of taurine. Cystine is present as a free amino acid only in those specimens from polluted water. It is proteinbound in M. edulis from both clean and polluted water. Methionine occurs in free form in all but the transferred specimens. It is also found as part of the proteins from $M$. edulis of both clean and polluted water. Cysteine appears only in the protein-bound form in those animals analyzed from polluted water.

If the spot that appeared in the position of taurine/asparagine on the chromatogram, is assumed to be, at least in part, taurine, then this amino acid appears in the free form in only those specimens transferred.

If the specimens taken from clean water can be considered as those with a normal metabolic pattern, then it can be safely postulated that the metabolism of methionine has not been altered in any except the transferred specimens, where it does not appear in free form. The presence of cystine as a free amino acid in individuals from polluted water suggests that some environmental factor has freed a portion of it from proteins or that an amount in excess of that utilized in protein formation has been synthesized. The possible appearance of free taurine in the transferred specimens and the total absence of free methionine suggests that some factor in the change of environment may have brought about the conversion of the latter to taurine.

The disappearance of proline in those specimens of $M$. edulis transferred from a clean to a polluted environment is unexplainable at present.

\section{SUMMARY}

In an attempt to determine the effects of water pollutants upon the wharf mussel, Mytilus edulis, the following analyses were made.

1. Specimens were collected from polluted waters. From these the free amino acid content of muscle tissue was analyzed by means of twodimensional paper chromatography. These were found to contain 14 identifiable free amino acids plus some (two in one instance, three in 
another) unidentifiable ninhydrin-sensitive spots.

2. Specimens from polluted waters were analyzed, after hydrolysis, for amino acid content of muscle tissue. Sixteen amino acids were identified. Unidentifiable spots also occurred in specimens from two of the three locations.

3. Specimens from nonpolluted water were treated in the same way. Thirteen free amino acids were identified. Cystine, present in free form from polluted water was lacking. Three unidentifiable spots were also present. Fourteen amino acids were identified from the protein hydrolysate. Cysteine and tyrosine, found in hydrolysates of polluted water specimens, were lacking here.

4. Specimens were transferred from clean water to polluted environments, left for 10 days, and then analyzed in the usual manner. Chromatograms showed them to have 11 free amino acids in common with the others. Proline and methionine contained in the others were absent here. Cystine, present in those native to the polluted areas, was lacking. Taurine/asparagine, not found in any of the others, appeared here.

\section{REFERENCES}

BLEVGAD, H. 1932. Investigations of the bottom fauna at outfalls of drains in the Sound. Copenhagen Rept. Danish Biol. Sta. 37:1-20.

Filice, Francis P. 1959. The effects of wastes on the distribution of bottom invertebrates in the San Francisco Bay Estuary. Wasmann J. Biol. 17 (1) : 1-17.
Hartman, Olga. 1956. Results on Investigations of Pollution and Its Effects on Benthonic Populations in Santa Monica Bay, California. Allan Hancock Foundation, Univ. So. Calif. Press. Pp. 1-23.

1959. The benthonic fauna of southern California in shallow depths and possible effects of wastes on the marine biota. Waste Disposal in the Marine Environment. Pergamon Press. Pp. 57-81.

McNulty, J. K. 1957. Pollution studies in Biscayne Bay during 1956. Progress Rept. Fed. Sec. Agency, PHS, NIH, Feb.: 1-17.

REISH, D. J. 1955. The relation of polychaetous annelids to harbor pollution. Public Health Rept. 70:1168-1174.

1956. An ecological study of Lower San Gabriel River, California, with special reference to pollution. Calif. Fish and Game $42(1): 51-61$.

$1957 a$. The effect of pollution on marine life. Industrial Wastes 2:114-118.

1957b. The relationship of the polychaetous annelid Capitella capitata (Fabricius) to waste discharges of biological origin. Biol. of Water Pollution. U. S. Public Health Service, Cincinnati. Pp. 195-200.

1960. The use of marine invertebrates as indicators of water quality. Waste Disposal in the Marine Environment. Pp. 92-103.

SCHAFER, R. D. 1961. Effects of pollution on the free amino acid content of two marine invertebrates. Pacif. Sci. 15(1):49-55.

WILHELMI, J. 1916. Übersicht über die biologische Beurteilung des Wassers. Ges. Naturf. Freunde Berlin, Sitzber.:297-306. 